\title{
Sprawozdanie z ogólnopolskiej, interdyscyplinarnej konferencji naukowej dla doktorantów i młodych naukowców pt. Kluczowe pojęcia myślenia historycznego: praktyczne wyzwania i teoretyczne innowacje współczesnej wiedzy o przeszłości, Poznań, 6-7 III 2020 r.
}

W dniach 6-7 marca 2020 r. w Sali Posiedzeń Poznańskiego Towarzystwa Przyjaciół Nauk odbyła się ogólnopolska interdyscyplinarna konferencja naukowa dla młodych naukowców pt. Kluczowe pojęcia myślenia historycznego: praktyczne wyzwania i teoretyczne innowacje wspótczesnej wiedzy o przeszłości. Głównymi organizatorami byli dr Anna Brzezińska z Instytutu Historii Uniwersytetu Łódzkiego, dr Piotr Kowalewski z Instytutu Historii Uniwersytetu Śląskiego oraz mgr Tomasz Wiśniewski z Wydziału Historii UAM, opiekę naukową zaś sprawowała prof. dr hab. Ewa Domańska również z Wydziału Historii UAM.

Uroczystego otwarcia konferencji dokonał dziekan Wydziału Historii UAM prof. dr hab. Józef Dobosz oraz prezes PTPN prof. UAM dr hab. Andrzej Gulczyński. Następnie głos zabrała prof. dr hab. Ewa Domańska, po której kwestie organizacyjne omówił mgr Tomasz Wiśniewski. Konferencję podzielono na dwa dni. W piątek 6 marca odbyły się cztery sesje, każda poświęcona innemu zagadnieniu. Podczas pierwszej z nich, traktującej o współczesnych problemach myślenia historycznego, można było wysłuchać dwóch referatów. Alicja Bemben (Instytut Literaturoznawstwa UŚ) opowiedziała o strukturze myślenia historycznego (Struktura myślenia historycznego a jego użyteczność społeczna). Następnie Jakub Muchowski (Instytut Historii UJ) przedstawił realia pisarstwa historycznego (Autonomia i estetyka pisarstwa historycznego). 
Następna sesja została poświęcona dziedzictwu, a rozpoczą ją referat o heritagizacji (Heritagizacja: czyli kiedy wszystko staje się dziedzictwem) autorstwa Moniki Stobieckiej (Wydział „Artes Liberales” UW). Po niej głos zabrała Karolina Wróbel-Bardzik (Instytut Kultury Polskiej UW), która opowiedziała o środowisku przyrodniczym jako wiedzy o przeszłości (Środowisko przyrodnicze jako pojęcie wspótczesnej wiedzy o przeszłości). Z kolei na pytanie „co porusza historię?” (Co porusza historię? Ruch jako medium poznania przeszłości) starał się odpowiedzieć Maciej Talaga (Wydział „Artes Liberales” UW), zamykając sesję.

Po przerwie obiadowej przystąpiono do kolejnej części obrad, którą podzielono również na dwie sesje. Pierwsza z nich dotyczyła pamięci i tożsamości, a rozpoczął ją wykład poświęcony analizie Dzienników Roberta Schumanna (Archeologia zatroskania. Dzienniki Roberta Schumanna 1827-1856), który wygłosiła Ada Arendt (Instytut Kultury Polskiej UW). Następnie o wspomnieniach jako źródle do badań historycznych (Prawdy pamięci - propozycje do badań nad geneza i ranga wspomnień) opowiedziała Małgorzata Gumper (Wydział Historii UAM). Ostatni referat w tej sesji dotyczył budowania tożsamości narodowej (Pojęcie zdrady a tworzenie nowoczesnej tożsamości narodowej) i został wygłoszony przez Artura Kulę (Instytut Badań Literackich PAN).

Ostatnia sesja została poświęcona historii cyfrowej i mediom społecznościowym, a mogliśmy podczas jej trwania wysłuchać dwóch referatów. Pierwszy z nich, autorstwa Marcina Wilkowskiego (Centrum Kompetencji Cyfrowych UW) dotyczył krytyki stron internetowych (Strona internetowa - problemy krytyki źródła). Z kolei Adrian Trzoss i Dawid Gralik (WH UAM) opowiedzieli o świadomości historycznej w mediach społecznościowych (Kategoria świadomości historycznej w mediach społecznościowych). Obrady w tym dniu zostały zakończone wykładem plenarnym pt. For a New Notion of History, or What Kind of Past Do We Need at the Time of the Anthropocene, który wygłosił prof. Marek Tamm z Uniwersytetu w Tallinie (Estonia).

Drugi dzień obrad składał się już tylko z dwóch sesji, na które wszystkich zgromadzonych zaprosiła prof. dr hab. Ewa Domańska. Pierwsza, poświęcona Holokaustowi i myśleniu historycznemu, została otwarta referatem autorstwa Katarzyny Grzybowskiej (Wydział Polonistyki UJ), która opisała miejsca walk i męczeństwa jako nie-miejsca pamięci (Nie-miejsca pamięci jako kategorie myślenia historycznego. Przykład miejsc walk i męczeństwa opisanych podczas Alertu ZHP z 1965 roku). Drugi wykład w tej części wygłosił Paweł Michna (Wydział Polonistyki UJ), który opisał refleksje badacza wobec propagandy wizualnej (Prospektywna polityka pamięci i jej preposteryjne odczytanie. Badacz wobec wizualnej propagandy „z Zagłady”). Następnie, 
o myśleniu historycznym izraelskiego historyka Saula Friedlandera (Apokaliptyczny kontekst przeszłości. Przykład myślenia historycznego Saula Friedlandera) opowiedział Maciej Sawicki (WH UAM).

Ostatnią sesję, poświęconą pozaeuropejskim kontekstom myślenia historycznego, otworzył wykład Kariny Gaibuliny (Cultural Studies Department University of St. Gallen / IKP UW), oscylujący wokół znaczenia terminu „Sybir” w myśleniu historycznym („Sybir” jako kluczowe pojęcie myślenia historycznego w XIX wieku. Przypadek Bronistawa Zaleskiego). Po nim o gramatyce historii ( $W$ poszukiwaniu gramatyki historii. Wzory kultury europejskiej a projekt luzofonii) opowiedział Karol Kasprowicz (Instytut Historii UMCS). Ostatni referat zarówno w tej sesji, jak i w całej konferencji, wygłosił Dawid Rogacz (Wydział Filozoficzny UAM), który odniósł się do chińskiej klasycznej filozofii historii (Kluczowe pojęcia klasycznej chińskiej filozofii historii). Podobnie jak dnia poprzedniego konferencję zamknął wykład plenarny, tym razem wygłoszony przez prof. Marię Poprzęcką z Wydziału „Artes Liberales” UW pt. Historia sztuki i historia w sztuce.

Konferencja cieszyła się dużym zainteresowaniem, o czym mogły świadczyć niekończące się dyskusje zarówno na sali posiedzeń, jak również w kuluarach. Uczestnicy i zaproszeni goście wyrazili nadzieję, że efektem obrad będzie tom pokonferencyjny oraz że do podobnego spotkania poświęconemu myśleniu historycznemu dojdzie w następnym roku.

Nadesłane: 15 IX 2020

Zaakceptowane: 27 IX 2020

mgr Jakub Wojtczak

Uniwersytet im. Adama Mickiewicza w Poznaniu

Wydział Historii

ul. Uniwersytetu Poznańskiego 7

61-614 Poznań

e-mail:kub.wojtczak@gmail.com 